\title{
TANGGUNG JAWAB SOSIAL DAN LINGKUNGAN BADAN USAHA MILIK MUHAMMADIYAH (BUMM) TERHADAP MASYARAKAT DAN LINGKUNGAN
}

\author{
Lelisari ${ }^{1}$ \\ Dosen Fakultas Hukum Universitas Muhammadiyah Mataram \\ Email: slelisari@gmail.com \\ DOI: $\underline{\text { https://doi.org/10.31764/jmk.v11i2.3084 }}$
}

Received: Agt 29, 2020, Accepted: Sept 30, 2020 /Published: Okt 31, 2020

\begin{abstract}
This article discusses the social and environmental responsibility of Muhammadiyah Owned Enterprises (BUMM). The establishment of the economic field as the third pillar in the muhammadiyah preaching as well as marking the characteristics of Advanced Islam that became the spirit of the Muhammadiyah da'wah movement. Speaking of Muhammadiyah, not only talk about schools and universities in the field of education or talk hospitals in the field of health, but also talk about factories and plantations owned by Muhammadiyah. The type of research used is normative juridical research, which is research focused on reviewing the application of rules or norms in positive law. As a result of the research, the Economic and Entrepreneurial Assembly has compiled guidelines for Muhammadiyah Owned Enterprises (BUMM) and has been socialized in 2017, namely the Muhammadiyah Central Leadership Guidelines No. 04/PED/I.0/B/ 2017 on Muhammadiyah Owned Enterprises. This guideline is drawn up, so that bumm management in the form of Limited Liability Company (PT) can be managed in accordance with Muhammadiyah's vision by accommodating good corporate governance. The application of social and environmental responsibility of Muhammadiyah Owned Enterprises (BUMM) to the community and the environment only provides money assistance and programs that are derma or philanthropic, have not touched on the environmental aspects. In The Guidelines No. 04/PED/I.0/B/ 2017 concerning Muhammadiyah Owned Enterprises also has not regulated the obligations of Muhammadiyahowned enterprises in carrying out CSR.
\end{abstract}

Keyword: BUMM; CSR.

\begin{abstract}
ABSTRAK
Artikel ini membahas tentang tanggung jawab sosial dan lingkungan Badan Usaha Milik Muhammadiyah (BUMM). Pencanangan bidang ekonomi sebagai pilar ketiga dalam dakwah persyarikatan Muhammadiyah sekaligus menandai ciri Islam berkemajuan yang menjadi spirit gerakan dakwah Muhammadiyah. Berbicara tentang Muhammadiyah, tidak hanya berbicara tentang sekolah dan perguruan tinggi di bidang pendidikan atau berbicara rumah sakit di bidang
\end{abstract}


kesehatan, tetapi juga berbicara pabrik-pabrik dan perkebunan yang dimiliki Muhammadiyah. Tipe penelitian yang digunakan adalah penelitian yuridis normatif yakni penelitian yang difokuskan untuk mengkaji penerapan kaidah-kaidah atau norma-norma dalam hukum positif. Hasil penelitian bahwa, Majelis Ekonomi dan Kewirausahaan sudah menyusun pedoman Badan Usaha Milik Muhammadiyah (BUMM) dan telah disosialisasikan pada tahun 2017, yaitu Pedoman Pimpinan Pusat Muhammadiyah Nomor 04/PED/I.0/B/ 2017 tentang Badan Usaha Milik Muhammadiyah. Pedoman ini disusun, supaya pengelolaan BUMM berbentuk Perseroan Terbatas (PT) bisa dikelola sesuai visi Muhammadiyah dengan mengakomodasi tata kelola perusahaan yang baik.Bentuk penerapan tanggung jawab sosial dan lingkungan Badan Usaha Milik Muhammadiyah (BUMM) terhadap masyarakat dan lingkungan hanya memberikan bantuan uang dan program yang sifatnya derma atau filantropi, belum menyentuh ke aspek lingkungan. Dalam Pedoman No 04/PED/I.0/B/ 2017 tentang Badan Usaha Milik Muhammadiyah juga belum mengatur tentang kewajiban dari badan usaha milik Muhammadiyah dalam melaksanakan CSR.

Kata Kunci: BUMM; CSR.

\section{PENDAHULUAN}

Bidang Pendidikan dan bidang kesehatan sudah menjadi pilar dakwah Persyarikatan Muhammadiyah, namun hasil Muktamar Muhammadiyah ke-47 di Makassar pada tahun 2015 lalu, dimana ekonomi sebagai pilar ketiga dakwah Muhammadiyah dianggap sangat strategis. Penguatan pilar ekonomi melalui usaha yang digerakkan oleh Muhammadiyah dan warga Muhammadiyah tidak hanya mencari laba semata, namun harus berdampak positif bagi umat dan bangsa. Pencanangan bidang ekonomi sebagai pilar ketiga Muhammadiyah ini juga untuk mendukung kemandirian Muhammadiyah.

Persyarikatan Muhammadiyah yang melintasi perjalanan usia satu abad senantiasa bersinggungan dan memiliki kaitan dengan berbagai permasalahan yang sedang dihadapi oleh umat manusia saat ini, baik dalam lingkup nasional maupun global, termasuk di dalamnya dinamika 


\section{Lelisari | Tanggung Jawab Sosial dan Lingkungan Badan Usaha Milik Muhammadiyah (BUMM)...}

kehidupan umat Islam. ${ }^{1}$ Pencanangan bidang ekonomi sebagai pilar ketiga sekaligus menandai ciri Islam berkemajuan yang menjadi spirit gerakan dakwah Muhammadiyah. Dengan pencanangan ini, diharapkan akan tumbuh amal usaha ekonomi Muhammadiyah di masa mendatang. Dengan demikian, ketika berbicara tentang Muhammadiyah, tidak hanya berbicara tentang sekolah dan perguruan tinggi di bidang pendidikan atau berbicara rumah sakit di bidang kesehatan, tetapi juga berbicara pabrik-pabrik dan perkebunan yang dimiliki Muhammadiyah.

Wakil Ketua Majelis Ekonomi dan Kewirausahaan (untuk selanjutnya disebut dengan MEK) PP Muhammadiyah dan juga wakil ketua Komite Pengarah Rakernas MEK dan Silaturahim Nasional JSM (Jaringan Saudagar Muhammadiyah) III Ahmad Syauqi Soeratno menjelaskan, pada Muktamar Muhammadiyah ke-47 pada 2015 di Makassar melahirkan komitmen untuk memajukan ekonomi persyarikatan sebagai pilar ketiga dakwah Muhammadiyah. Menanggapi hal tersebut MEK harus membuat beberapa program, karena dalam hal ini MEK tidak beranjak dari nol sudah ada Amal Usaha Muhammadiyah (untuk selanjutnya disebut dengan AUM) dan badan usaha yang bergerak. AUM sendiri merupakan lembaga bersifat sosial, di mana MEK bekerja sama dengan majelis-majelis terkait dalam Muhammadiyah untuk pengembangannya. Misi utamanya untuk menggali dan mengembangkan tiap AUM. ${ }^{2}$

Ada beberapa badan usaha milik Muhammadiyah (untuk selanjutnya disebut dengan BUMM) dan perseroan terbatas (untuk selanjutnya disebut dengan PT) di berbagai daerah yang juga memiliki

1 Mappanyompa, M., \& Imawanto, I. 2019. “Problematika Pengkaderan di Perguruan Tinggi Muhammadiyah Mataram dalam Perspektif Norma Pengkaderan Muhammadiyah. Media Keadilan: Jurnal Ilmu Hukum. https:// doi.org/10.31764/jmk.v10i1.1106, Hal 83.

2 Pratiwi, Fuji. Pengembangan Usaha Muhammadiyah Berdampak Bagi Umat, September, 2017. Diakses melalui https://www.republika.co.id/berita/nasional/sangpencerah/17/09/14/ow9qvw291-pengembangan-usaha-muhammadiyah-berdampak-bagi-umat 
AUM, untuk BUMM, MEK sudah menyusun pedoman BUMM dan telah disosialisasikan pada tahun 2017, yaitu Pedoman Pimpinan Pusat Muhammadiyah Nomor 04/PED/I.0/B/ 2017 tentang Badan Usaha Milik Muhammadiyah. Pedoman ini disusun, supaya pengelolaan BUMM berbentuk PT bisa dikelola sesuai visi Muhammadiyah dengan mengakomodasi tata kelola perusahaan yang baik. Di dalamnya diatur kewenangan komisaris, direksi, pemegang saham, pengelolaan keuangan, dan sebagainya.

Mengingat Muhammadiyah adalah organisasi keumatan dan memiliki kewajiban layanan publik (PSO) atau tanggung jawab sosial perusahaan (Corporate Social Responsibility (CSR)) untuk melayani umat. Akan tetapi selama ini, sebagian besar masyarakat menganggap bahwa melaksanakan CSR cukup hanya memberikan bantuan uang dan program yang sifatnya derma atau filantropi.

CSR berkaitan juga dengan Socially Responsible Investment (SRI), dimana lingkungan merupakan bagian CSR yang paling mendasar. Lingkungan merupakan suatu isu yang diadaptasi dari paraktik SRI. Isu $S R I$ pada awalnya terbatas pada isu alkohol, pertahanan dan tembakau. ${ }^{3}$

Di Indonesia, etika bisnis yang berkaitan dengan CSR telah diformulasikan dalam hukum positif sebagaimana telah diatur dalam Undang-Undang No 4 Tahun 2009 tentang Pertambangan Mineral dan Batubara, Pasal 108, Undang-Undang No 25 Tahun 2007 tentang Penanaman Modal, Pasal 15 butir b, Undang-Undang No 40 Tahun 2007 Tentang Perseroan Terbatas, Pasal 74, dan Peraturan Pemerintah No 47 Tahun 2012 Tentang Tanggung Jawab Sosial dan Lingkungan Perseroan Terbatas, Undang-Undang No 9 Tahun 2003 tentang Badan Usaha Milik Negara, Pasal 2 jo Pasal 66 ayat (1) dan Peraturan Menteri Badan Usaha

\footnotetext{
3 Sparkers, Russel. (2002). Socially Responsible Investment A global Revolution, (San Fransisco: John Wiley \& Son, Ltd, 2002). Hal. 119
} 
Milik Negara Nomor Per-05/MBU/2007 tentang Program Kemitraan Badan Usaha Milik Negara dengan Usaha Kecil dan Program Bina Lingkungan, serta Peraturan Daerah di berbagai daerah kabupaten/kota di Indonesia.

Dengan adanya berbagai aturan yang mengatur tentang kewajiban melaksankan CSR, maka selayaknya BUMM yang berbentuk PT wajib melaksanakan CSR untuk kepentingan masyarakat dan lingkunga, maka sangat penting dan menarik untuk dilakukan kajian hukum mengenai Penerapan Tanggung Jawab Sosial dan Lingkungan Badan Usaha Milik Muhammadiyah (BUMM) terhadap masyarakat dan lingkungan.

\section{METODOLOGI}

Sebagai konsekuensi pemilihan topik permasalahan yang akan dikaji dalam penelitian yang objeknya adalah permasalahan hukum (sedangkan hukum adalah kaidah atau norma yang ada dalam masyarakat) maka tipe penelitian yang digunakan adalah penelitian yuridis normatif yakni penelitian yang difokuskan untuk mengkaji penerapan kaidah-kaidah atau norma-norma dalam hukum positif. Pendekatan yang digunakan dalam yuridis normatif adalah pendekatan perundang-undang dan pendekatan konseptual.

\section{PEMBAHASAN}

Amal usaha Muhammadiyah berfungsi sebagai wadah bagi persyarikatan untuk mewujudkan cita-cita Muhammadiyah. Amal usaha sejatinya bisa dijadikan sarana untuk memperoleh profit, akan tetapi jika ditarik kembali kepada tujuan Muhammadiyah maka amal usaha yang awalnya profit oriented nantinya harus menunjang aktivitas persyarikatan yang sifatnya non-profit. Hal ini yang kemudian membedakan amal usaha dengan perusahaan lainnya. Sehingga dibutuhkan suatu konsep tata 
kelola atas amal usaha Muhammadiyah yang tidak hanya mengacu pada prinsip kewajaran, transparansi, akuntanbilitas, dan responsibilitas. Akan tetapi hal tersebut perlu dikemas secara apik dalam bingkai amanah untuk mengharmonisasikan tujuan amal usaha dengan cita-cita suci Muhammadiyah. ${ }^{4}$

Beberapa tahun terakhir, di organisasi Muhammadiyah mulai familiar dengan istilah Badan Usaha Milik Muhammadiyah. Istilah ini digulirkan untuk menyebut beberapa usaha Muhammadiyah yang murni mencari keuntungan atau profit oriented agar dapat dipisahkan dengan kegiatan lainnya yang sifatnya non-profit. Sebenarnya sah-sah saja untuk membuat istilah itu, karena memang jika ditilik dari pengertiannya, Badan Usaha merupakan sebuah lembaga resmi berbadan hukum yang menaungi dan menjalankan unit-unit usahanya. Sehingga bisa dikatakan Muhammadiyah itu sendiri sebenarnya adalah sebuah badan usaha. ${ }^{5}$

Persyarikatan Muhammadiyah adalah merupakan organisasi Islam modern yang bergerak dalam bidang dakwah amar ma'ruf nahi munkar dan tajdid yang diwujudkan dalam usaha disegala bidang kehidupan. Bahwa untuk mewujudkan pelaksanaan program Muhammadiyah yang efektif dan efesien dalam perencanaan, pengorganisasian, pembimbingan dan pelaksanaan, dan pengawasan amal usaha dibidang ekonomi, perlu adanya pedoman pimpinan pusat Muhammadiyah tentang badan usaha milik Muhammadiyah (BUMM). Dimana pedoman tersebut sudah disusun dengan maksud supaya pengelolaan BUMM berbentuk PT bisa dikelola sesuai visi Muhammadiyah dengan mengakomodasi tata kelola perusahaan yang

${ }^{4}$ Hafni, Diska Arliena dan Harventy, Gina, Membingkai Good Corporate Governance Amal Usaha Muhammadiyah Dalam Kerangka Amanah. Journal of Accounting and Investment, Universitas Muhammadiyah Yogyakarta, 2013. Vol 14 No 2 P-ISSN :2622- 3899, E-ISSN : 2622-2431. Hal. 85-95. Diakses melalui http://journal.umy.ac.id/index.php/ai/article/view/1277

${ }^{5}$ Andi Azhar, Saat Amal Usaha Berubah Menjadi Badan Usaha, Source: https://www.andiazhar.com/2018/04/saat-aum-berubah-menjadi-bumm.html. 
baik. Di dalamnya diatur kewenangan komisaris, direksi, pemegang saham, pengelolaan keuangan, dan sebagainya. Pedoman tersebut sudah dibuat oleh Pimpinan Pusat Muhammadiyah pada tanggal 3 Februari 2017 dengan Nomor 04/PED/I.0/B/ 2017 tentang Badan Usaha Milik Muhammadiyah.

Ada beberapa BUMM dan Perseroan Terbatas di berbagai daerah yang juga memiliki AUM, untuk BUMM, seperti Pimpinan Daerah Muhammadiyah (untuk selanjutnya disebut dengan PDM) yaitu PDM Wonosobo yang telah mendirikan PT. Berkah Sejahtera Mandiri (BEST). PT BEST adalah perseroan yang bergerak dalam segala bidang, mengingat kebutuhan percepatan persyarikatan dalam berbagai bidang terutama untuk mensupport financial sekaligus memutar keuangan dikantong sendiri. 6

Kemudian, PDM Ponorogo mengembangkan sayap dakwahnya melalui bidang ekonomi kerakyatan dengan mendirikan Baitul Mal wa Tamwil (BMT), Swalayan, Bank Perkreditan Rakyat (BPR), Bank Pembiayaan Rakyat Syariah (BPRS) dan lembaga penyiaran publik atau radio. Dari usaha ekonomi tersebut terdapat empat jenis kegiatan dengan badan hukum yang berbentuk PT.7

Dalam Pedoman No 04/PED/I.0/B/ 2017 tentang Badan Usaha Milik Muhammadiyah terdiri 13 BAB dan 23 Pasal, belum mengatur mengenai kewajiban melaksanakan Tanggung jawab sosial perusahaan (CSR) dari Badan Usaha Milik Muhammadiyah.

\footnotetext{
${ }^{6}$ Hans-MPI Wonosobo.. Muhammadiyah Wonosobo Sinergitaskan Peran Amal Usaha. (2018, April) Diakses melalui http://www.umm.ac.id/id/muhammadiyah/13647.html

7 Sugeng Wibowo, Penyertaan Modal Organisasi Dalam Badan Hukum Perseroan Terbatas (PT) di Amal Usaha Milik Persyarikatan Muhammadiyah Kabupaten Ponorogo. 2016. Jurnal Ekuilibrium Fakultas Ekonomi Universitas Muhammadiyah Ponorogo Vol 8. No 2. ISSN 2528-7672, hal 24-34. Diakses melalui https://www.researchgate.net/publication/323517690_PENYERTAAN_MODAL_ORGANISASI_ DALAM_BADAN_HUKUM_PERSEROAN_TERBATAS_PT_DI_AMAL_USAHA_MILIK_PERSYA RIKATAN_MUHAMMADIYAH_KABUPATEN_PONOROGO. DOI: 10.24269/ekuilibrium.v8i2.40
} 
Adapun prinsip dari badan usaha milik Muhammadiyah adalah sebagai berikut:

1. Jujur

2. Amanah

3. Unggul

4. Orientasi misi

5. Taat pada persyarikatan

6. Profesional

7. Akuntabel

8. Transparan

9. Impersonal

10. Kemaslahatan umum

Berdasarkan prinsip yang dimiliki oleh BUMM sebenarnya sudah mencakup sebagian tentang prinsip Good Corporate Governance (GCG) atau prinsip tata kelolah perusahaan yang baik yang merupakan perpaduan penerapan lima prinsip GCG, yaitu: transparency, accountability, responsibility, independency, dan fairness. Dalam BUMM hanya mencakup tiga dari lima prinsip GCG yaitu mengenai prinsip jujur, akuntabilitas dan transparan. Responsibility dan Independency belum tertera dalam prinsip BUMM.

Penerapan tanggung jawab sosial perusahaan untuk kepentingan stakeholders dalam etika bisnis dimaksud untuk memperkuat jalannya perusahaan, dengan cara membangun kerjasama antara stakeholders yang difasilitasi oleh perusahaan yang bersangkutan dengan jalan menyusun program-program pengembangan masyarakat sekitarnya, atau dalam pengertian kemampuan perusahaan untuk beradaptasi dengan lingkungan, komunitas dan stakeholders yang terkait dengan perusahaan, baik lokal, nasional dan gobal, karena pengembangan CSR kedepan mengacu pada konsep pembangunan yang berkelanjutan. Penerapan 
prinsip Good Corporate Governance (GCG) yang sekaligus penerapan tanggung jawab sosial perusahaan, merupakan perpaduan penerapan lima prinsip GCG, yaitu: transparency, accountability, responsibility, independency, dan fairness secara harmonis. Tiga prinsip yang cenderung bersifat shareholders driven karena lebih memperhatikan kepentingan pemegang saham perusahaan yaitu fairness bisa berupa perlakuan yang adil terhadap pemegang saham minoritas, transparancy menunjuk pada penyajian laporan keuangan yang akurat dan tepat waktu, sedangkan accountability diwujudkan dalam bentuk fungsi dan kewenangan RUPS, komisaris, dan direksi yang baru dipertanggung jawabkan. Dalam rangka menciptakan GCG, CSR harus memadukan lima prinsip GCG secara harmonis. Kearifan lokal yang selama ini ada dimasyarakat merupakan akar dari kepedulian lingkungan yang tidak tertulis namun berlaku dalam masyarakat secara turun temurun. Kearifan lokal dapat memperkuat penerapan tanggung jawab sosial perusahaan untuk kepentingan stakeholders. ${ }^{8}$

Dalam beberapa referensi, konsep tanggung jawab sosial Perusahaan (CSR) sudah dijelaskan dan diuraikan. CSR adalah suatu aktifitas korporasi yang dapat diwajibkan oleh hukum. Ruang lingkup tanggung jawab sosial perusahaan sebaiknya tidak perlu dibatasi secara kaku dan penerapan tanggung jawab sosial perusahaan di Indonesia menghendaki kejelasan pengaturan dari peraturan perundang-undangan yang ada, kewajiban CSR tidak bisa dimaknai sempit sebagai bentuk penyaluran sebagian kekayaan perusahaan kepada masyarakat, untuk mendukung iklim usaha yang kondusif, pemerintah harus mendorong korporasi untuk melaksanakan CSR dengan memberikan pengurangan pajak. Mengenai berbagai bentuk pelaksanaan CSR oleh Perusahaan Multi Nasional,

\footnotetext{
8 Ketaren, Marianne Magda, Penerapan Tanggung Jawab Sosial Lingkungan Perusahaan untuk Kepentingan Stakeholders. (Medan: Disertasi Program Doktor Ilmu Hukum Fakultas Hukum Universitas Sumatera Utara, Medan. 2014)
} 
Perusahaan Swasta Nasional dan Badan Usaha Milik Negara yang sudah berjalan, baik dengan nama community development, program kemitraan dan bina lingkungan, donasi dan lain sebagainya harus dianggap sebagai bentuk dari pelaksanaan CSR. ${ }^{9}$

Menurut Busyra Azheri, prinsip CSR sebenarnya sudah diakomodasi di dalam UU No 4 tahun 2009 tentang Minerba tetapi masih bersifat implisit dan atau sumir, kecuali pada pasal tentang pembinaan dan pemberdayaan masyarakat sekitar lingkungan pertambangan.Penerapan CSR di bidang pertambangan juga bersifat dual sistem. Bagi Badan Usaha Milik Negara (BUMN) penerapannya telah bersifat keharusan (mandatory) dalam makna kewajiban hukum (legal obligation), karena telah diatur sedemikian rupa. Sedangkan bagi Badan Usaha Milik Swasta (BUMS), penerapan CSR masih bersifat sukarela (voluntary) meskipun telah diatur dalam UU Penanaman Modal, UUPT dan UU Minerba dengan motif reaktif dalam bentuk kedermawanan. ${ }^{10}$

Adapun bentuk CSR yang dilakukan oleh amal usaha Muhammadiyah yang bergerak dibidang pendidikan, seperti Universitas Muhammadiyah Yogyakarta yaitu memberikan kontribusi dalam pelaksanaan pembangunan dan pemberdayaan masyarakat di Kabupaten Bantul selama 2019. Kemudian, Universitas Ahmad Dahlan yang mengimplementasikan CSR nya dalam bentuk pengalokasian anggaran Corporate Social Responsibility (CSR) sebesar 2,5\% dari pendapatan. Dimana dana tersebut diperuntukkan bagi masyarakat luas termasuk di dalamnya program Maju Bersama Persyarikatan. Beberapa

\footnotetext{
${ }_{9}^{9}$ Mukti, Fadjar ND, Tanggung Jawab Sosial Perusahaan di Indonesia: Mandatory vs Voluntary (Studi tentang Penerapan Ketentuan Corporate Social Responsibility pada Perusahaan Multinasional, Swasta Nasional dan Badan Usaha Milik Negara). (Jakarta: Disertasi Program Doktor Ilmu Hukum Fakultas Hukum Univesitas Indonesia, Jakarta. 2009).

10 Busyra, Azheri, Tanggung Jawab Sosial Perusahaan dan Lingkungan Kegiatan Pertambangan di Sumatera Barat. (Malang: Disertasi Program Doctor Ilmu Hukum Fakultas Hukum Univesitas Brawijaya, Malang. 2010).
} 
CSR telah diberikan kepada masyarakat yang mengalami musibah bencana alam, kegiatan-kegiatan masyarakat, dan persyarikatan.

Dalam amal usaha Muhammadiyah yang bergerak di bidang kesehatan, seperti, Rumah Sakit PKU Muhammadiyah Karanganyar rutin menyalurkan Rp 78 juta dan CSR dalam bentuk BPJS Kesehatan kepada warga tidak mampu. Penerapan CSR hanya memberikan bantuan uang dan program yang sifatnya derma atau filantropi.. ${ }^{11}$

Sebenarnya disaat AUM sudah berubah menjadi BUMM dengan bentuk badan usaha PT yang sektor usahanya beragam mulai dari percetakan, alat kesehatan, properti, agro, perkebunan dan lain-lain, sudah wajib melaksanakan tanggung jawab sosial perusahaan. Hal ini sesuai dengan ketentuan Undang-Undang No 40 Tahun 2007 Tentang Perseroan Terbatas Pasal 74 ayat, menyatakan:

(1)Perseroan yang menjalankan kegiatan usahanya dibidang dan/atau berkaitan dengan sumber daya alam wajib melaksanakan Tanggung Jawab Sosial dan Lingkungan

(2)Tanggung Jawab Sosial dan Lingkungan sebagaimana dimaksud pada ayat (1) merupakan kewajiban perseroan yang dianggarkan dan diperhitungkan sebagai biaya perseroan yang pelaksanaannya dilakukan dengan memperhatikan kepatutan dan kewajaran

(3)Perseroan yang tidak melaksanakan kewajiban sebagaimana dimaksud pada ayat (1) dikenakan sanksi sesuai dengan ketentuan perundangundangan.

Kemudian, dalam UU No 25 Tahun 2007 Tentang Penanaman Modal Pasal 15 huruf b, menyatakan: setiap penanaman modal berkewajiban melaksanakan tanggung jawab sosial perusahaan. Oleh karenanya, selayaknya Pedoman No 04/PED/I.0/B/ 2017 tentang Badan Usaha Milik Muhammadiyah, mengacu pada ketentuan yang ada dalam peraturan

\footnotetext{
11 Rustam Aji. Rutin RS PKU Muhammadiyah Karanganyar Salurkan Dana CSR dalam Bentuk BPJS Kesehatan Kepada warga Tidak Mampu, 16 Desember 2018, diakses melalui https:// pwmjateng.com/rutin-rs-pku-muhammadiyah-karanganyar-salurkan-78-juta-dana-csrdalam-bentuk-bpjs-kesehatan-kepada-warga-tidak-mampu/
} 
perundang-undangan. Terutama yang berkaitan dengan ketentuan tanggung jawab sosial dan perusahaan.

\section{SIMPULAN}

Bentuk penerapan tanggung jawab sosial dan lingkungan Badan Usaha Milik Muhammadiyah (BUMM) terhadap masyarakat dan lingkungan hanya memberikan bantuan uang dan program yang sifatnya derma atau filantropi, belum menyentuh ke aspek lingkungan. Dalam Pedoman No 04/PED/I.0/B/ 2017 tentang Badan Usaha Milik Muhammadiyah juga belum mengatur tentang kewajiban dari badan usaha milik Muhammadiyah dalam melaksanakan CSR. Pedoman ini disusun, supaya pengelolaan BUMM berbentuk Perseroan Terbatas (PT) bisa dikelola sesuai visi Muhammadiyah dengan mengakomodasi tata kelola perusahaan yang baik, namun prinsip dalam BUMM hanya mencakup tiga dari lima prinsip GCG yaitu mengenai prinsip jujur, akuntabilitas dan transparan. Responsibility dan Independency belum tertera dalam prinsip BUMM. Dalam mengelola BUMM sesuai dengan visi Muhammadiyah dengan mengadopsi GCG dan untuk mewajibkan BUMM yang berbentuk PT menerapkan prisip CSR sesuai dengan Undang-Undang, dalam Pedoman No 04/PED/I.0/B/ 2017 tentang Badan Usaha Milik Muhammadiyah seharusnya direvisi dan menyesuaikan dengan peraturan yang ada.

\section{DAFTAR PUSTAKA}

\section{Buku}

Sparkers,Russel. (2002). Socially Responsible Investment A global Revolution, (San Fransisco: John Wiley \& Son, Ltd).

Aji, Rustam. (2018, Desember). Rutin RS PKU Muhammadiyah Karanganyar Salurkan Dana CSR dalam Bentuk BPJS Kesehatan Kepada warga 
Tidak Mampu, 16 Desember 2018, diakses melalui

https://pwmjateng.com/rutin-rs-pku-muhammadiyah-

karanganyar-salurkan-78-juta-dana-csr-dalam-bentuk-bpjs-

kesehatan-kepada-warga-tidak-mampu/

\section{Jurnal, Disertasi, Website}

Azheri, Busyra. (2010). "Tanggung Jawab Sosial Perusahaan dan Lingkungan Kegiatan Pertambangan di Sumatera Barat". (Malang: Disertasi Program Doctor Ilmu Hukum Fakultas Hukum Univesitas Brawijaya, Malang).

Fadjar, Mukti, ND. (2009). "Tanggung Jawab Sosial Perusahaan di Indonesia: Mandatory vs Voluntary (Studi tentang Penerapan Ketentuan Corporate Social Responsibility pada Perusahaan Multinasional, Swasta Nasional dan Badan Usaha Milik Negara)". (Jakarta: Disertasi Program Doktor Ilmu Hukum Fakultas Hukum Univesitas Indonesia, Jakarta).

Ketaren, Marianne Magda. (2014). "Penerapan Tanggung Jawab Sosial Lingkungan Perusahaan untuk Kepentingan Stakeholders". (Medan: Disertasi Program Doktor Ilmu Hukum Fakultas Hukum Universitas Sumatera Utara, Medan.)

Hafni, Diska Arliena dan Harventy, Gina. (2013). “Membingkai Good Corporate Governance Amal Usaha Muhammadiyah Dalam Kerangka Amanah". Journal of Accounting and Investment, Universitas Muhammadiyah Yogyakarta, Vol 14 No 2 P-ISSN :2622- 3899, E-ISSN : 2622-2431. Hal. 85-95. Diakses melalui http://journal.umy.ac.id/index.php/ai/article/view/1277

Hans-MPI Wonosobo. (2018, April). Muhammadiyah Wonosobo Sinergitaskan Peran Amal Usaha. Diakses melalui http://www.umm.ac.id/id/muhammadiyah/13647.html 
Pratiwi, Fuji. (2017, September). Pengembangan Usaha Muhammadiyah Berdampak Bagi Umat. Diakses melalui https://www.republika.co.id/berita/nasional/sangpencerah/17/09/14/ow9qvw291-pengembangan-usaha$\underline{\text { muhammadiyah-berdampak-bagi-umat }}$

Wibowo, Sugeng. (2016). “Penyertaan Modal Organisasi Dalam Badan Hukum Perseroan Terbatas (PT) di Amal Usaha Milik Persyarikatan Muhammadiyah Kabupaten Ponorogo". Jurnal Ekuilibrium Fakultas Ekonomi Universitas Muhammadiyah Ponorogo Vol 8. No 2. ISSN 2528-7672, hal 24-34. Diakses melalui

https://www.researchgate.net/publication/323517690_PENYE $\underline{\text { RTAAN_MODAL_ORGANISASI_DALAM_BADAN_HUKUM }}$ _PERSEROAN_TERBATAS_PT_DI_AMAL_USAHA_MILIK_P ERSYARIKATAN_MUHAMMADIYAH_KABUPATEN_PONO ROGO. DOI: 10.24269/ekuilibrium.v8i2.40

\section{Perundang-Undangan}

Indonesia. Undang-Undang Dasar Negara Kesatuan Republik Indonesia 1945.

Indonesia. Undang-Undang No 9 Tahun 2003 tentang Badan Usaha Milik Negara.

Indonesia. Undang-Undang No 40 Tahun 2007 Tentang Perseroan Terbatas. No 106 Tambahan Lembaran Negara Republik Indonesia Nomor 4756.

Indonesia. Undang-Undang No 25 Tahun 2007 Tentang Penanaman Modal. Lembaran Negara Republik Indonesia Tahun 2007 Nomor 67. Tambahan Lembaran Negara Republik Indonesia Nomor 4724. 
Indonesia. Undang-Undang No 4 Tahun 2009 Tentang Pertambangan Mineral dan Batu Bara, Lembaran Negara Republik Indonesia Nomor 4959.

Indonesia. Undang-Undang No 32 Tahun 2009 Tentang Perlindungan dan Pengelolaan Lingkungan Hidup, Lembaran Negara Republik Indonesia Nomor 5059.

Indonesia. Peraturan Pemerintah No 47 Tahun 2012 Tentang Tanggung Jawab Sosial Perseroan Terbatas. Tambahan LN Republik Indonesia Nomor 5305.

Indonesia. Peraturan Menteri BUMN No: Per-05/MBU/2007 Tentang Program Kemitraan Badan Usaha Milik Negara Dengan Usaha Kecil dan Program Bina Lingkungan.

Indonesia. Pedoman Pimpinan Pusat Muhammadiyah Nomor 04/PED/I.0/B/ 2017 tentang Badan Usaha Milik Muhammadiyah (BUMM). 